\title{
Natural Law in Reformed Thinking
}

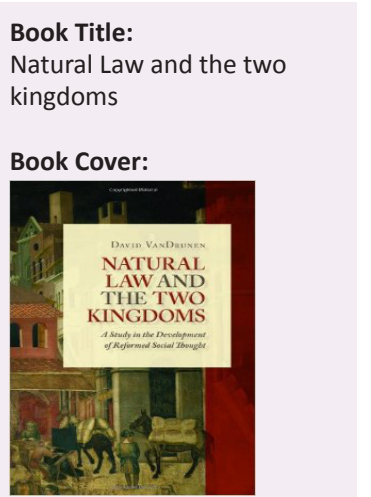

Author:

David VanDrunen

ISBN:

978-0-8028-6443-7

\section{Publisher:}

Emory University Studies in

Law and Religion, Eerdmans, 2009, \$38.00*

*Book price at time of review

\section{-}

Review Title:

Natural Law in Reformed

Thinking

Reviewer:

Jakobus M. (Koos) Vorster ${ }^{1}$

\section{Affiliation:}

${ }^{1}$ Faculty of Theology,

North-West University,

Potchefstroom Campus,

South Africa

Email:

editor@inluceverbi.org.za

Postal address:

3 Goedehoopstreet,

Potchefstroom 2531,

South Africa

How to cite this book review: Vorster, J.M., 2014, 'Natural Law and the two kingdoms', In die Skriflig 48(1), Art. \#1851, 2 pages. http://dx.doi org/10.4102/ids.v48i1.1851

\section{Copyright:}

(C) 2014. The Authors. Licensee: AOSIS OpenJournals. This work is licensed under the Creative Commons Attribution License.

\section{Read online:}

In a 2006 publication entitled Rediscovering the Natural Law in Reformed Theological Ethics (Eerdmans, Grand Rapids, Michigan) Stephan J. Grabill notes the re-appreciation of natural law in reformed theological ethics after the concept was pushed to the background owing to Karl Barth's influence during the late 20th century. Barth and his followers rebelled against any form of natural theology in reaction to National Socialism. In the process they criticised the very idea of natural law. Grabill shows how the idea gained importance again within theological ethics during a time when ethics had to develop a moral foundation to ward off the wave of secularism that is currently placing the Christian faith under pressure.

VanDrunen contributes to the revalorisation of natural law with his incisive and thought provoking publication. He discusses the doctrine of the two kingdoms (the City of God and the city of man) as it developed from the Reformation onwards as well as the connection that several prominent theologians, legal scholars and philosophers have established between the two kingdoms, natural law and politics in social thought. He also discusses the development of the doctrine of the two kingdoms before the Reformation in an introductory chapter. In doing so, VanDrunen refers to the ancient document, the Didache, which presents two ways of living, namely the spiritual and the real. Each person is driven by unique principles. The Letter of Diognetus takes a similar view. According to VanDrunen, Augustine drew from these documents in the development of his doctrine on the two kingdoms. Christians reside in the City of God and may not practice the morality of the city of man, which is, in Augustine's view, representative of the Roman Empire. The political and spiritual realm should not intermingle and should not be associated with each other. With this teaching, Augustine laid the foundation for the relationship between church and society as it developed throughout history. The same idea later surfaced with Luther, who distinguished between the civil and the spiritual realms. The civil realm is regulated by Natural Law and the spiritual realm by the Decalogue. However, natural law is not entirely secular, because it comes from God. The Decalogue is a summary of Natural Law.

VanDrunen shows in the rest of his book how this doctrine of the two kingdoms was expanded and applied to social thought and legal philosophy throughout the history of reformed theology with a few differences in emphasis in some instances. He probes Calvin's view of the matter extensively. Calvin distinguished between State and Church and although he did not always succeed in doing so in the organisation of the city-state Genève, Calvin attempted to apply this distinction consistently. He departed from the view that the law and political morality are founded in natural law, whereas the church is guided by the Word and the Decalogue. In a 2007 publication The Reformation of Rights. Law, Religion and Human Rights in Early Modern Calvinism (Cambridge University Press, Cambridge) J. Witte also provided a thorough explication of Calvin's thought on natural law. VanDrunen offers some more valuable insights on this matter.

He continues to reveal how the doctrine of two kingdoms and natural law were upheld and expressed in constitutional law. He also describes how it became part of the development of constitutional thought in New England and the important development of the Virginia Bill. The Presbyterian tradition ensured that Calvinist thought and the idea of a constitutional state took root in American constitutional thought. VanDrunen also examines the views of Abraham Kuyper and the neo-Calvinists, which included the legal philosophy of Dooyeweerd and the views of Van Til and his followers.

A study on natural law will not be complete if it does not revisit Karl Barth's criticism on the notion of natural law as he explains it in his polemics with Brunner. VanDrunen reveals how Barth, although he did invoke Calvin, in this respect deviated from the Calvinist tradition with his passionate rejection of natural law.

VanDrunen's well-documented publication is an important contemporary contribution to the development of Christian ethics in the face of biblicism on the one hand and secularism on the other. He directs reformed ethicists towards the developing of a meta-theory for ethical 
consideration that is applicable to contemporary ethical issues by using the concept of the two kingdoms and natural law, as it has developed in the reformed tradition. The book can be recommended for scholars in disciplines such as theological ethics and legal philosophy due to its wellsubstantiated documentation and arguing. A subsequent publication by VanDrunen appeared recently in which he provides a biblical-theological foundation for Natural Law (see VanDrunen, D., 2014, Divine Covenants and Moral Order. A Biblical Theology of Natural Law, Eerdmans, Grand Rapids Michigan/Cambridge, UK.). A later issue of In die Skriflig will offer a review of this book also. 